\title{
Hikorocodium Endo is Not an Alga but an Inozoid Sponge
}

\author{
J. Keith Rigby \\ Baba Senowbari-Daryan
}

Follow this and additional works at: https://scholarsarchive.byu.edu/facpub

Part of the Geology Commons

\section{Original Publication Citation}

Senowbari-Daryan, Baba, and J. Keith Rigby. "Hikorocodium Endo is Not an Alga but an Inozoid Sponge." Canadian Journal of Earth Sciences = Revue Canadienne des Sciences de la Terre 44.2 (27): 149-54.

\section{BYU ScholarsArchive Citation}

Rigby, J. Keith and Senowbari-Daryan, Baba, "Hikorocodium Endo is Not an Alga but an Inozoid Sponge" (2007). Faculty Publications. 931.

https://scholarsarchive.byu.edu/facpub/931 accepted for inclusion in Faculty Publications by an authorized administrator of BYU ScholarsArchive. For more information, please contact ellen_amatangelo@byu.edu. 


\title{
Hikorocodium Endo is not an alga but an inozoid sponge
}

\author{
Baba Senowbari-Daryan and J . Keith Rigby
}

\begin{abstract}
The genus Hikorocodium, with the type species Hikorocodium elegantae from the Permian of Japan, was described originally as a codiacean alga by Endo. It is not a codiacean alga but an inozoid sponge of the family Preperonidellidae. Several fossils described later by Endo and other authors as H. elegantae should be assigned to different inozoid sponge taxa. Specimens of H. fertiliz, described by Endo from the Jurassic of Japan, are also sponge fragments. The taxonomic positions of $H$. transversum Endo and H. kuramotoi Nakamura, as sponges or algae, remain uncertain.
\end{abstract}

Résumé : Le genre Hikorocodium, dont l'espèce type est H. elegantae du Permien du Japon, a été décrit à l'origine par Endo comme faisant partie des algues codiacées Il ne s'agit toutefois pas d'algues codiacées, mais plutôt d'éponges inozoïdes de la famille des Préperonidellidés. Plusieurs fossiles décrits par la suite par Endo et d'autres auteurs comme étant Hikorocodium elegantae sont plutôt attribuables à différents taxons d'éponges inozoïdes. Des spécimens d'Hikorocodium fertilis du Jurassique du Japon décrits par Endo sont également des fragments d'éponges. Les positions taxonomiques d'H. transversum Endo et $H$. kuramotoi Nakamura, plus précisément leur attribution aux éponges ou aux algues, demeurent incertaines.

[Traduit par la Rédaction]

\section{Introduction}

Endo (1951) described a calcareous fossil from the Kitakami Mountains of northeastern Japan that he named Hikorocodium, and assigned it to the codiacean algae. He and other authors later described and illustrated the same or similar fossils as Hikorocodium several times, based on specimens from Japan, Europe, and northern Africa (see synonymy under "Systematic paleontology" later in the text). He later added two more species, $H$. transversum Endo (1957) and H. fertiliz Endo (1961b), to Hikorocodium. An additional species was described as $H$. kuramotoi by Nakamura (1994) from the Carboniferous of Japan. H. kuramotoi has also been reported from the Carboniferous of the Cantabrian Mountains, Spain (Mamet and Villa 2004).

Codiaceans are a nodular or blade-shaped group of calcareous algae with aragonitic skeletal mineralogy. The thallus in this group consists of a central zone (medula with siphons arranged parallel to the axis) and a peripheral zone (cortex with smaller branched utricles arranged perpendicular or oblique to the axis or to the medullar zone). Utricles of the cortex zone are clearly branched tubes or pores. However,

Received 6 December 2005. Accepted 20 June 2006.

Published on the NRC Research Press Web site at

http://cjes.nrc.ca on 5 April 2007.

Paper handled by Associate Editor B. Chatterton.

B. Senowbari-Daryan. Institute of Paleontology, University Erlangen-Nürnberg, Loewenichstrasse 28, D-91054 Erlangen, Germany.

J. Keith Rigby. ${ }^{\mathbf{1}}$ Department of Geology, S-389 Eyring Science Center, Brigham Young University, Provo, UT 84602-4606, USA.

${ }^{1}$ Corresponding author (e-mail: rigbyjkeith@qwest.net). the internal structure of Hikorocodium has a reticulate structure and not "atubular pores in the peripheral part" as noted by Endo (1951, p. 126; 1961a, p. 29). The spongelike character of Hikorocodium was also evident to him. He observed that "The central stem may be composed of a sponge-like mass of very fine rounded thread-like filaments." (Endo 1951, p. 126). The totally different internal structures of Hikorocodium and codiacean algae may be the reason that neither Bassoullet et al. (1983) nor Granier and Grgasovic (2000) listed Hikorocodium among the codiacean or dasycladacean algae. However, skeletal characteristics of the type species, $H$. elegantae Endo, are typical of inozoid sponges. Kochansky and Herak (1960), H.W. Flügel (1963), and Vachard (in Termier et al. 1977) discussed the systematic position of Hikorocodium. They listed it as under "problematica" or "incertae sedis".

\section{Heterogeneity of fossils known as Hikorocodium}

Endo (1951) described H. elegantae in detail, but unfortunately he did not give a summarized diagnosis nor designate a specimen as holotype for the genus. He summarized a diagnosis for Hikorocodium (Endo 1961a, p. 29), "Thallus cylindrical rather straight or somewhat undulating. It is composed of a poorly organized, pith-like, central stem and may be composed of a sponge-like mass of very fine rounded thread-like filaments. The tubular pores are given off from the central stem at about right angles or slightly ascending toward one end of the thallus." (see also Vachard, in Termier et al. 1977, p. 24).

The "type material" of $H$. elegantae described by Endo includes three specimens he illustrated (Endo 1951, pl. 10, figs. 1-3). Figures 1 and 2 illustrate specimens with longitudinal sections that exhibit a relatively wide axial canal (called "central stem" by Endo) surrounded by an irregularly 
Fig. 1. Various species of Hikorocodium that have been figured by previous authors. (A-C) Hikorocodium elegantae Endo. Original illustrations by Endo (1953, pl. 10, figs. 1-3). Explanations and magnification of all three figures as given by him, $\times 3$. (Endo 1951, p. 128) (A, B) "Longitudinal sections showing undulated outlines, rounded protuberances, and branched, anastomosing, tubular pores which end blindly near the outer surface." (C) "A cross-section of a specimen showing a just-dividing point of bifurcating central stem, coated with dark layers of some kind of sponge." (D, E) Hikorocodium elegantae Endo. Both figures were illustrated by Endo (1957, pl. 42, figs. 5, 6). Explanations and magnifications are as given by him (Endo 1951, p. 128) . (D) "Well preserved cross-section showing anastomosing tubular pores, $\times 15$." (E) "Longitudinal section, $\times 10$." (F) Hikorocodium elegantae Endo. Only one specimen was figured by Endo and Horiguchi (1957, pl. 14, fig. 3). The explanation and magnification, according to the authors (Endo 1957, p. 301) are, "A tangential section, showing characteristic anastomosing branched tubular pores, ×25." (G) Hikorocodium sp., illustrated by Wray, (1977, fig. 87, p. 85,) with the explanation, "Longitudinal and transverse section. Permian, Tunisia. Transmitted light, thin section." (H) Hikorocodium elegantae Endo, illustrated by Flügel (1980, pl. 2, fig. 7, p. 56). The explanation and magnification of the transverse section, according to the author are, "Querschnitt, $\times 15$."

arranged, loose fibrous structure characteristic of sponges. The endowall (wall of the axial canal) is not distinct. The third specimen, illustrated as fig. 3 , is a cross-section that exhibits two axial canals surrounded by relatively coarse and densely packed fibrous structure. The axial canals are separated from one another by a thin wall and each canal has a distinct wall. Endo explained this figure as "a specimen of cross-section showing the division point of bifurcating central stem, coated with dark layers of some kind of sponge" (Endo 1951, p. 129).

In our opinion, the specimens illustrated in figs. 1 and 2 by Endo (1951) are of the same species, but the specimen shown in fig. 3 does not belong to this species. Therefore, two different sponge species were assigned to $H$. elegantae by Endo (1951).

Endo did not designate a holotype for $H$. elegantae. However, he noted (Endo 1951, p. 127) "Genotypes:-L.E.S., Saitama Univ., Slides No. 41, 59, 60, Specimen, 10769”. Because the description of $H$. elegantae by Endo (1951) was based mainly on the longitudinal sections of specimens illustrated in figs. 1 and 2, we designate the specimen shown in fig. 2 as the "lectotype" (Fig. 1B) and that in fig. 1 as a "paralectotype" (Fig. 1A) for H. elegantae. Figure 3 in Endo (1951) represents an inozoid sponge with two axial spongocoels (Fig 1C), a feature characteristic of the genera Bisiphonella Wu (1991); Bicoelia Rigby, Senowbari-Daryan, and Liu (1998); or Imperatoria de Gregorio (1930). However, these three genera cannot be distinguished in transverse sections (see Rigby and Senowbari-Daryan 1996, p. 81; Rigby et al. 1998).

Endo (1953, pl. 12, fig. 8, p. 124) later described and illustrated another example of $H$. elegantae from the Lower Permian of the Iwaizaki Limestone, from about $80 \mathrm{~km}$ northeast of Sendai. This poorly preserved specimen also seems to be a sponge, like the type material of Endo (1951), and could be assigned to $H$. elegantae Endo.

Specimens described and illustrated as $H$. elegantae by Endo (1954b, pl. 19, figs. 1-3, p. 218) seem to be a different form. The specimens shown in figs. 1 and 3 differ markedly from the type material of Endo (1951) and also from another specimen he later illustrated (Endo 1954b, fig. 2). All three of these specimens are sponges, however, and are not algae.

Endo (1957, pl. 42, figs. 5, 6, p. 297) described and illustrated two additional specimens as Hikorocodium elegantae (Figs. 1D, 1E). These specimens, particularly the one shown in cross-section in Endo's figure 6, have an axial canal surrounded by a coarse fibrous skeletal structure. These speci- mens are also inozoid sponges. Such sponges are known from the Carboniferous and Permian, and were described as Maeandrostia by Girty (1908) (see Finks and Rigby 2004, p. 644). Wray (1977, fig. 87, p. 84) described and illustrated as Hikorocodium two transverse sections of sponges from the Upper Permian of Tunisia that could be Maeandrostia (Fig. 1G).

A specimen from the Carboniferous of the Hida Massif, Japan, was described and illustrated as Hikorocodium elegantae by Endo and Horiguchi (1957, pl. 14, fig. 3, p. 176) (Fig. 1F). It also seems to be different from the type specimens illustrated by Endo (1951). The structure of this later specimen is comparable with that of the sponge described as Vermispongia spiniformis Wu 1991 (= Vermispongiella spiniformis Finks and Rigby 2004, p. 607) from the Permian of China.

In addition, Endo (1961c, pl. 7, p. 135) described and illustrated a specimen as $H$. elegantae from the Permian of Honshû Island, Japan. This specimen is differentiated from all other specimens described by Endo in earlier publications by its large axial canal and five (six?) collateral vertical canals located near the periphery of the skeleton. This specimen belongs to the preperonidelliid inozoid sponge genus Heptatubispongia, and the same sponge species was described as $H$. symmetrica by Rigby and Senowbari-Daryan (1996) from the Upper Permian of Tunisia and by Senowbari-Daryan et al. (2005) from the Permian of Iran.

Two specimens of sponges from the Lower Permian of the Kitakami Mountains, northeastern Japan, were described and illustrated as $H$. elegantae by Horiguchi (1958, pl. 27, fig. 3; pl. 28, fig. 7; pp. 137-138; see later in the text under "Systematic paleontology" for an explanation of plate and figure numbering). Figure 3 in plate 27 illustrates transverse section of a sponge with an axial spongocoel surrounded by skeletal fibers without exhalant or inhalant canals, and it may be a Preperonidella. The oblique transverse section of the specimen illustrated by fig. 7 in plate 28 clearly shows a large axial spongocoel and nine (or 10?) collateral peripheral canals that are characteristic features of Heptatubispongia symmetrica Rigby and Senowbari-Daryan (1996).

Kochansky and Herak (1960, pl. 10, figs. 9-13, p. 90) described and illustrated different sponges from the Permian of several localities in the former Yugoslavia as Hikorocodium elegantae Endo. For example, the specimen shown in their fig. 13 has two axial canals, like the specimen illustrated by Endo (1951, pl. 10, fig. 3), and should be assigned to Bisiphonella Wu (1991) or to Bicoelia Rigby, Senowbari- 

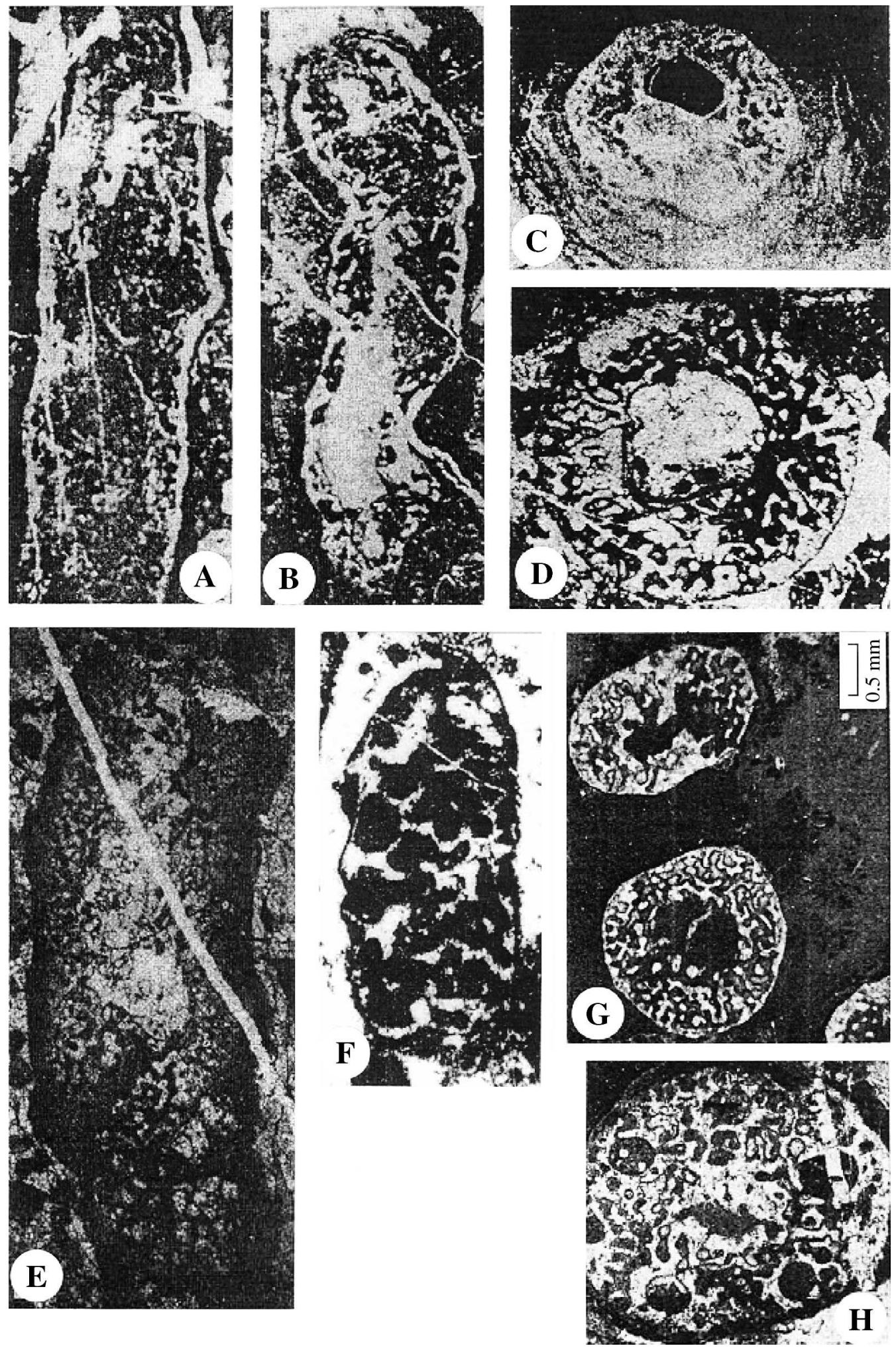

Daryan, and Liu (1998). None of the specimens illustrated by Kochansky and Herak are comparable to other specimens illustrated by Endo (1951, pl. 10, figs. 1, 2). Kochansky and Herak (1960, p. 90) interpreted Hikorocodium as a problematic organism. They wrote that "In our slides from various localities we find numerous specimens which are identical with those published by Endo (1954a, 1957), Endo and
Horiguchi (1957), and Horiguchi (1958) as Hikorocodium elegantae. However, it is necessary to note that in our opinion the organization can not be regarded as doubtlessly typical dasycladacean. A slight general similarity with Hydrozoa was the reason that some of our specimens were first published as 'cf. Carterina sp.' or 'Stromatoporidae gen. et sp. indet.'." 
H.W. Flügel (1963) described sponge-like fossils from the Permian of Dizdere bei Julfa, Iran, and from Ala Dag, Taurus Mountains, Turkey, as Hikorocodium elegantae Endo, and attributed them to problematic organisms. He noted that Hikorocodium could be a sponge.

H.W. Flügel (1963, p. 92) synonymized the fossils described as "Carta sp. n. sp A and n. sp. B" (Hydrozoa) by E. Flügel (1959) from the Permian of Slovenia and Crna Gera, Montenegro. E. Flügel (1959, fig. 1) illustrated only the species "Carta sp. n. sp. A". There is no illustration of "Carta sp. n. sp. B" from the Crna Potok locality, Montenegro.

The cross-section of "Carta sp. n. sp. A" illustrated by E. Flügel (1959) in fig. 1 shows an axial cavity. Apparently E. Flügel (1959, p. 90) interpreted this cavity as a "Fremdkörper" (extraneous object). The skeletal structure of his "Carta" is totally different from Hikorocodium. The taxonomic position of E. Flügel's Carta sp. n. sp. A and B as hydrozoans or sponges is doubtful.

Hikorocodium was listed as a genus of "uncertain affinities" by Johnson (1964). He reillustrated (Johnson 1964, pl. 45, fig. 1) an enlarged view Endo's original material (Endo 1951, pl. 10, fig. 1). He gave Endo's original description of the genus and type species (Johnson 1964, p. 38) and noted that "The description and original illustration do strongly suggest a rather poorly preserved green alga." (Johnson 1964, p. 39). However, later descriptions (Endo 1953, pl. 12, fig. 8, p. 124; pl. 4, fig. 3, p. 176; Endo 1957, pl. 42, figs. 5-7, p. 297298) add little information, whereas the illustrations progressively show specimens that look less and less like algal material, ending with Endo's 1957 illustration of Permian specimens and Endo's 1961c Jurassic paper where the illustrations really suggest stromatoporoids.

Kochansky-Devidé (1970, pl. 26, fig. 5, p. 220) described and illustrated a specimen as Hikorocodium elegantae Endo that exhibits two spongocoels. This inozoid specimen belongs to either Bicoelia Rigby, Senowbari-Daryan, and Liu (1998) or Bisiphonella Wu (1991).

Homann (1972, pl. 2, fig. 15, p. 181) described and illustrated a specimen, from the Carnic Alps, Austria, as Hikorocodium elegantae Endo. It is not possible to be certain about skeletal details and classification of the specimen based on his illustration.

The specimen illustrated by E. Flügel (1980, pl. 2, fig. 7) as Hikorocodium elegantae Endo, from the lower Permian (Trogkofel beds) of the Carnic Alps, shows the large axial and small collateral canals (Fig. 1H) typical of Heptatubispongia symmetrica Rigby and Senowbari-Daryan 1996.

Nakazawa (2002, pl. 29, fig. 5) illustrated several specimens that were considered by him to be Hikorocodium. According to his description, "This incertae sedis has a tube form with inner pores." (Nakazawa 2002, p. 198) and in his photographs these specimens may be algae but are not Hikorocodium comparable to the type material of Endo (1951).

In summary, Hikorocodium was not accepted as a certain alga and was listed as a problematic alga by algal specialists (e.g., Kochansky and Herak 1960; H.W. Flügel 1963; Johnson 1964; Kochansky-Devidé 1970; Vachard, in Termier et al. 1977). Some fossils that were described in the literature as Hikorocodium elegantae Endo should be assigned taxonomically to several different sponge genera. They are clas- sified within the hypercalcified Demospongea in the following section.

A small specimen of questionable taxonomy, but referred to as Hikorocodium? sp., was described and figured by Rigby, Fan, and Han (1995) from the Upper Permian of western Hubei Province, China. They concluded that the silicified specimens they had were not suitable for detailed comparisons with other forms of the genus, but suggested that the genus should be re-examined by researchers with better material to make a taxonomic evaluation of the genus.

\section{Systematic paleontology}

Class Demospongea Sollas, 1875

Subclass Ceractinomorpha Lévi, 1953

Order Agelasida Verrill, 1907

Family Preperonidellidae Finks and Rigby, 2004

Subfamily Preperonidellinae Finks and Rigby, 2004

Genus Hikorocodium Endo, 1951

TYPE SPECIES: Hikorocodium elegantae Endo, 1951.

EMENDED DIAGNOSIs: Cylindrical inozoid sponges with a relatively wide axial spongocoel equal to approximately $40 \%$ of whole sponge diameter. Sponge skeleton composed of loose irregular or reticular fibrous elements. A cortex (outer wall of sponge) well developed and pierced by openings of different size. Endowall (wall of spongocoel) is not distinct.

1951 Hikorocodium elegantae n. sp.- Endo, pl. 10, figs. 1, 2, pp. 126-127 (non fig. 3, which is an inozoid sponge attributed to Bicoelia).

? 1953 Hikorocodium elegantae Endo.- Endo, pl. 12, fig. 8, p. 124.

1954a Hikorocodium elegantae Endo.- Endo, pl. 14, fig. 6, pp. 201-202.

$1954 b$ Hikorocodium elegantae Endo.- Endo, pl. 19, fig. 2, pp. 218-219 (non figs. 1, 3; these species are also sponges but gen. et sp. indet.).

? 1957 Hikorocodium elegantae Endo.- Endo, pl. 42, fig. 5, pp. 297-298.

non 1957 Hikorocodium elegantae Endo.- Endo, pl. 42, fig. 6, pp. 297-298 (it is a Maeandrostia).

non 1957 Hikorocodium elegantae Endo.- Endo and Horiguchi, pl. 14, fig. 3, p. 176 (may be Vermispongiella Finks and Rigby 2004, p. 607, pro Vermispongia Wu 1991).

non 1958 Hikorocodium elegantae Endo.- Horiguchi, pl. 27, fig. 3, pp. 137-138 (not pl. 28, fig. 7).

non 1960 Hikorocodium elegantae Endo.- Kochansky and Herak, pl. 9, figs. 9-13, p. 90 (different sponges with one or two spongocoels).

non 1961c Hikorocodium elegantae Endo.- Endo, pl. 4, fig. 7, p. 135 (see Heptatubispongia).

? 1963 Hikorocodium elegantae Endo.- H. W. Flügel, pl. 2, fig. 2, p. 92.

non 1970 Hikorocodium elegantae Endo.- Kochansky-Devidé, pl. 26, fig. 5, p. 220 (sponges with two spongocoels).

? 1972 Hikorocodium elegantae Endo.- Homann, pl. 2, fig. 15, pp. 181-183.

non 1977 Hikorocodium Endo.- Wray, fig. 87, p. 84 (may be Maeandrostia). 
Fig. 2. Heptatubispongia symmetrica Rigby and Senowbari-Daryan 1996, holotype from the Upper Permian of Djebel Tebaga, Tunisia, USNM 463724. (A) Side view of branched holotype with weakly annulate growth lines, $\times 2$. (B) Summit view, with left branch as shown in Fig. A as upper branch, with minor axial canals and symmetrically distributed vertical canals near the periphery, $\times 4$. (C) Base of sponge with typical ring of exhalant canals near the periphery and radial canals around the central spongocoel, $\times 8$. (D) Summit of right branch with characteristic canal pattern, $\times 5$ (from Rigby and Senowbari-Daryan 1996, pl. 33, figs. 9-12).


? 1977 Hikorocodium elegantae Endo.- Vachard (in Termier et al.), p. 24 (no illustration).

non 1980 Hikorocodium elegantae Endo.- E. Flügel, pl. 56, fig. 7 (see Heptatubispongia).

non 2002 Hikorocodium Nakazawa, pl. 29, fig. 5 (may be an alga but not Hikorocodium comparable with type material of Endo 1951).

DISCUSSION: The diagnosis presented earlier in the text is based on two longitudinal specimens illustrated by Endo (1951, pl. 10, figs. 1, 2) (Figs. 1A, 1B).

Endo (1957, pl. 42, fig. 7; pl. 43, figs. 1-3; p. 298).

A third species of Hikorocodium, H. fertiliz, was described and illustrated by Endo (1961b, pl. 10, fig. 1; pl. 14, fig. 5; pl. 17, fig. 5; pp. 66-67) from Upper Jurassic limestone, Fukushima-ken in Endo (1961b, p. 66) or Tokushima-ken in Endo (1961b, p. 72), Japan. Endo designated "Slide No. 684" (1961b, p. 66) as the holotype of $H$. fertiliz and illustrated it in fig. 5 of plate 17 (Endo 1961b). According to Endo, an enlargment of that holotype was illustrated in fig. 1 of plate 10 (Endo 1961b; the same enlargment was reillustrated by Johnson 1964, pl. 45, fig. 1), but this figured material does not correspond to any part of the holotype. Both specimens of $H$. fertiliz illustrated by Endo are fragments of undetermined sponges and should be excluded from the algae.

Finally, the fourth species was described as Hikorocodium kuramotoi by Nakamura (1994) from the Carboniferous of Japan. The systematic position of this species is uncertain.

Subfamily Heptabubispongiinae Rigby and SenowbariDaryan, 1996

\author{
Genus Heptatubispongia Rigby and Senowbari-Daryan, \\ 1996
}

TYPE SPECIES: Heptatubispongia symmetrica Rigby and Senowbari-Daryan, 1996.

ORIGINAL DIAGNOSIS: "Cylindrical to branched sponge with relatively large axial canal or spongocoel, and usually seven but in some specimens with as few as six or as many as eight or more collateral vertical canals located near periphery of sponge. Outer surface bears a few ostia. Internal structure characterized by relatively coarse reticulate fibers. Growth lines prominent on exterior." (Rigby and Senowbari-Daryan 1996, p. 83).

1958 Hikorocodium elegantae Endo.- Horiguchi, pl. 28, fig. 7 (non pl. 27, fig. 3).

1961c Hikorocodium elegantae Endo.- Endo, pl. 4, fig. 7, p. 135.

1977 Graminospongia girtyi (Parona).- Termier and Termier, pl. 8 , fig. 1.

1980 Hikorocodium elegantae Endo.- E. Flügel, pl. 56, fig. 7 .

1996 Heptatubispongia symmetrica n. sp.- Rigby and Senowbari-Daryan, pl. 33, figs. 9-16, pl. 49, fig. 9, pp. 83-84.

2005 Heptatubispongia symmetrica Rigby and SenowbariDaryan.- Senowbari-Daryan, Rashidi and Hamedani, figs. 11.1$11.5,13.1 \mathrm{H}$ and $2 \mathrm{H}$ (synonymy), p. 395.

OCCURRENCE: Heptatubispongia symmetrica (Figs. 2A-2D) is an abundant preperonidelliid inozoid sponge, occurring in Permian deposits of Tunisia (Rigby and Senowbari-Daryan 1996), the Carnic Alps of Austria (Flügel 1980), Japan (Horiguchi 1958, Endo 1961c), Sicily (material of SenowbariDaryan, see Senowbari-Daryan and Di Stefano 1988) and in Iran (Senowbari-Daryan et al. 2005).

\section{Acknowledgments}

The investigations were carried out within the framework of Project "Se 416/10" supported by the Deutsche Forschungsgemeinschaft to B. S.-D. We thank Dr. S.H. Vaziri (Tehran, currently in Japan) for his help in procuring copies of Endo's publications from Japan. We appreciate the constructive reviews of M.G. Carrera and D. Janussen, and the editorial assistance of Associate Editor Brian Chatterton. Brooks Britt aided in preparation of the photographic figures.

\section{References}

Bassoullet, J.P., Bernier, P., Deloffre, R., Génot, P., Poncet, J., and Roux, A. 1983. Les Algues Udoteacées du Paléozoique au Cénozoique. Bulletin des Centres de Recherches ExplorationProduction Elf-Aquitaine, 7(2): 449-621.

De Gregorio, A. 1930. Sul Permiano di Sicilia (Fossil del calcare con Fusulina di Palazzo Adriano). Annales de Géologie et Paleontologie, 52, pp. 1-70.

Endo, R. 1951. Stratigraphical and paleontological studies of the later Paleozoic calcareous algae in Japan I. Transactions and Proceedings of the Palaeontological Society Japan, new series, 5: 121-129.

Endo, R. 1953. Stratigraphical and paleontological studies of the later Paleozoic calcareous algae in Japan, V. Japanese Journal of Geology and Geography, 23: 117-126. 
Endo, R. 1954a. Stratigraphical and paleontological studies of the later Paleozoic calcareous algae in Japan, VIII. Several species from Kinsho-zan, Akasamachi, Gifu-ken. The Science Reports of Saitama University, Sciences Report, series B, 1(3): 209-216.

Endo, R. 1954b. Stratigraphical and paleontological studies of the later Paleozoic calcareous algae in Japan, IX. The Science Reports of Saitama University, series B, 1(3): 217-221.

Endo, R. 1957. Stratigraphical and paleontological studies of the later Paleozoic calcareous algae in Japan, XI. The Science Reports of Saitama University, series B, 2(3): 281-305.

Endo, R. 1961a. Phylogenetic relationships among the calcareous algae. In Biology and earth sciences. Commemorative Vol. The Science Reports of Saitama University, series B, pp. 1-52.

Endo, R. 1961b. Calcareous algae from the Jurassic Torinosu Limestone of Japan. In Biology and earth sciences. Commemorative Vol. The Science Reports of Saitama University, series B, pp. 53-75.

Endo, R. 1961c. Stratigraphical and paleontological studies of the Later Paleozoic calcareous algae in Japan, XVII. Fossil algae from the Acacia Limestone Group. In Biology and earth sciences. Commemorative Vol. The Science Reports of Saitama University, series B, pp. 119-141.

Endo, R., and Horiguchi, M. 1957. Stratigraphical and palaeontological studies of the later Paleozoic calcareous algae in Japan, XII. Fossil algae from the Fukuji District in the Hida Massif. Japanese Journal of Geology and Geography, 28(4): 169-177.

Finks, R.M., and Rigby, J.K. 2004. Hypercalcified sponges. In Treatise on invertebrate paleontology, Part E. Vol. 3. Edited by R.L. Kaesler. The Geological Society of America and University of Kansas, Lawrence, Kans. pp. 585-764.

Flügel, E. 1959. Hydrozoen aus dem oberen Perm von Slovenija und Crna Gora. Geologija, 5: 86-91.

Flügel, E. (Editor). 1980. Die mikrofazies der kalke in den TrogkofelSchichten der Karnischen Alpen. In Die Trogkofel-Stufe im Unterperm der Karnischen Alpen. Carinthia II. Sonderheft, 36, pp. 51-99.

Flügel, H.W. 1963. Algen und Problematica aus dem Perm Süd-Anatoliens und Irans. Sitzungsberich mathematischnaturwissenschaftliche Klasse Österreich, I: 85-95.

Girty, G.H. 1908. On some new and old species of Carboniferous fossils. Proceedings of the United States National Museum, 34: 181-303.

Granier, B.R.C., and Grgasovic, T. 2000. Les algues dasycladales du Permian et du Trias. Nouvelle tentative d'inventaire bibliographique, géographique et stratigraphique. Geologia Croatia, 32(1): 1-197.

Homann, W. 1972. Unter- und tief mittelpermische kalkalgen aus den Rattendorfer Schichten, dem Trogkofel-Kalk und dem Tressdorfer Kalk der Karnischen Algen (Österreich). Senckenbergiana Lethaea, 5(3/4): 135-313.
Horiguchi, M. 1958. Some calcareous algae in the central part of the Kitakami Mountains, Iwate Prefecture, northern Japan. The Science Reports of Saitama University, series B, 3(1): 131-139.

Johnson, J.H. 1964. The Jurassic algae. Quarterly of the Colorado School of Mines, 59(2): 1-129.

Kochansky, V., and Herak, M. 1960. On the Carboniferous and Permian Dasycladaceae of Yugoslavia. Geoloski Vjesnik, 13: 65-94.

Kochansky-Devidé, V. 1970. Permiski mikrofosili zahodnih Karavank. Geologija, 13: 65-94.

Mamet, B., and Villa, E. 2004. Calcareous marine algae from the Carboniferous (Moscovian-Gzhelian) of the Cantabrian zone (NW Spain). Rivista Espanola de Paleontologia, 19(2): 151-190.

Nakamura, M. 1994. Algal remains from the Akiyoshi Limestone Group. Bulletin, Akiyoshi-Dai Museum of Natural History, 29: $1-45$.

Nakazawa, T. 2002. Carboniferous reef succession of the Panthalassian open-ocean setting: Example from Omi Limestone, central Japan. Facies, 44: 183-210.

Rigby, J.K., and Senowbari-Daryan, B. 1996. Upper Permian inozoid, demospongid, and hexactinellid sponges from Djebel Tebaga, Tunisia. The University of Kansas, Paleontological Contribution, new series, 7, pp. 1-130.

Rigby, J.K., Jiasong, F., and Nairen, H. 1995. Upper Permian silicified sponges from central Guangxi and western Hubei, South China. Journal of Paleontology, 69: 232-250.

Rigby, J.K., Senowbari-Daryan, B., and Liu, H. 1998. Sponges of the Permian Upper Capitan Limestone, Guadalupe Mountains, New Mexico and Texas. Brigham Young University Geology Studies, 43: 19-117.

Senowbari-Daryan, B., and Di Stefano, P. 1988. Microfacies and sphinctozoan assemblage of some Lower Permian breccias from the Lercara Formation (Western Sicily). Rivista Italiana Paleontology e Stratigraphy, 94(1): 3-34.

Senowbari-Daryan, B., Rashidi, K., and Hamedani, A. 2005. Sponge assemblage from the Permian reefal limestones of Kuh-e Bagh-e Vang, Shotori Mountains (eastern Iran). Geologica Carpathica, 56(5): 381-406.

Sollas, W.J. 1875. Sponges. In Encyclopedia Britannica. 9th ed. Adam and Charles Black, Edinburgh, pp. 427-446.

Termier, H., and Termier, G. 1977. Structure et évolution des spongiaires hypercalcifiés du Paléozoique supérieur. Memore de l'Institut Geologique, Universite Catholique de Louvain, 29: 57-109.

Termier, H., Termier, G., and Vachard, D. 1977. Monographie paléontologique des affleurements Permiens du Djebel Tebaga (Sud Tunisien). Palaeontographica, Abteilung A, 156(1-3): 1-109.

Wray, J. L. 1977. Calcareous algae. Elsevier, Amsterdam, The Netherlands.

Wu, Y.Sh. 1991. Organisms and communities of Permian Reef of Xiangbo, China. International Academic Publishers, Beijing, China. 
Copyright of Canadian Journal of Earth Sciences is the property of NRC Research Press and its content may not be copied or emailed to multiple sites or posted to a listserv without the copyright holder's express written permission. However, users may print, download, or email articles for individual use. 